\title{
NOVAS DETERMINAÇÕES SOBRE AS QUESTÕES REGIONAL E URBANA APÓS 1980*
}

\author{
WiLSON CANO
}

R E S U M O Entre 1930 e 1980 as principais determinaçôes sobre nossa urbanização, integração do mercado nacional e desenvolvimento regional decorreram basicamente da industrialização, da política macroeconômica e de políticas de desenvolvimento regional. Após 1980, com a "Década perdida" e as politicas neoliberais, aquelas determinaçōes foram em grande parte modificadas pelas novas formas de nossa inserçāo externa, pelo câmbio apreciado e juro alto, e pela Guerra Fiscal. Assim, além dos determinantes anteriores - enfraquecidos -, há os novos, de sentido nacional, sendo alguns específicos a cada regiāo. Em que pese as mudanças, os efeitos nocivos de nossa forma de crescer e de nossa urbanização se transmitiram a todo o território nacional. $O$ artigo se encerra com uma proposta de Agenda de Pesquisa sobre os temas regional e urbano para o período 1980-2010, com intuito de entender melhor aquelas determinaçôes e efeitos desses processos.

P A L A V R A S - C H A V E Questão regional; urbanização; novos determinantes; guerra fiscal; fronteira agro-mineral; inserção externa.

Este texto visa um exame e reflexão sobre os principais efeitos das mudanças mais relevantes sofridas pelo padrão de crescimento vigente após 1980, que causaram profundas alterações sobre as determinações mais gerais que agem sobre os processos de desenvolvimento regional e de urbanização brasileiros. Esse período de análise se situa entre 1980, com a "Crise da Dívida" e a posterior adoção de políticas neoliberais, estendendo-se até 2010.

No primeiro tópico, e para comparação com o restante do texto, farei breve síntese sobre as anteriores determinaçôes, as ocorridas entre 1930 e 1980, destacando, contudo o transcurso da década de 1970. No segundo tópico o objetivo central é desenhar e justificar uma agenda de pesquisa para o período 1980-2010, indagando as novas determinaçôes mais gerais daqueles processos. Para tanto, se fará um esforço teórico e metodológico que possa dar conta da realidade do período. Desde já tenho consciência do tamanho da tarefa e que sua realização só será possível com um grande esforço coletivo de pesquisa.

Obviamente, ao longo de todo esse processo, a questão ambiental ganhou relevância no debate nacional, face à degradação que ocorre, principalmente, no período pós 1980, seja pela extensão do desmatamento ou pela contaminação das principais bacias hidrográficas, seja pelas várias formas degradantes que se multiplicam no processo de urbanização (lixo, água, esgoto, ar, paisagem, enchentes etc.). Contudo, dada a dimensão e escopo deste artigo e, principalmente, a complexidade envolvida nesse tema, não tratarei do referido processo, embora o entenda como uma das questóes prioritárias a examinar nos temas da questão regional e da urbanização. 
1 Para este tópico, apóiome basicamente em Cano (2007a, b).

\section{AS PRINCIPAIS DETERMINAÇÕES NO PADRÃO ANTERIOR (1930 A 1970 E 1970 A 1980) ${ }^{1}$}

A ruptura política e econômica desencadeada pela "Crise de 29" e pela Revolução de 1930, fez a economia do Brasil transitar do antigo modelo "primário exportador" (de crescimento para fora), para o da industrialização (crescimento para dentro), mudando o "centro dinâmico da economia", e alterando as bases do antigo padrão de acumulação, que passa a ter no investimento autônomo sua principal determinação.

Isto reforçou a internalização de tomada de decisões, notadamente na órbita do Estado, que implantou, gradativamente, uma Política Nacional de Desenvolvimento, ampliando sobremodo suas funções de estímulo, indução e ação diretas, com forte ampliação do gasto e do investimento públicos.

A despeito da Depressão e da II Guerra, o novo padrão acelerou o crescimento do PIB, cuja taxa média anual, entre 1930 e 1970, atingiu 6\%, ou seja, bem acima dos 4,3\% da média 1900-1930. O PIB da indústria de transformação cresceu ainda mais, entre 1930 e 1970 , a $8,2 \%$ com o que a participação desse setor no PIB saltou, de cerca de $12,5 \%$ para 29,3\% em 1970.

A política econômica reforçou sobremodo o inexorável processo de integração do mercado nacional, que a industrialização desencadearia. Para isso muito colaboraram, além de outras medidas, os investimentos públicos em infraestrutura, que estreitaram a enorme dispersão territorial do país. Os investimentos industriais, públicos e privados, além de elevar a capacidade produtiva do setor, diversificaram-na, com a implantação da indústria de bens de produção e de consumo durável. A expansão regional, no período, caracterizou-se por uma forma de complementaridade com a economia de São Paulo, intensificando-se bastante o comércio inter-regional do país.

Embora tenha ocorrido enorme concentração da produção da indústria de transformação em São Paulo - que passa de 40,7\% para 58,2\% do total nacional entre 1939 e 1970 -, isso não causou qualquer perda absoluta a nenhuma das demais regiôes do país. Com efeito, enquanto esse setor cresceu, entre 1939 e 1970, à taxa média nacional de 8,1\%, a de São Paulo foi de 9,3\% e a do agregado Brasil-SP, de 6,9\%. Mesmo o Nordeste, a região que mais perdeu participação relativa, obteve a elevada taxa de 5,9\%.

A produção agropecuária do país também cresceu satisfatoriamente, em torno de 3,7\% anuais, intensificando-se também as trocas de várias regiões com São Paulo. Os destaques maiores para esse setor, no período, foram:

- a profunda transformação, modernização e diversificação do agro paulista, reduzindo a cafeicultura e expandindo, notadamente, a cana de açúcar e o algodão, que inibiriam, a longo prazo, essas culturas no NE. Isto provocou um grande fluxo de saída de pequenos produtores e trabalhadores rurais que migrariam, fundamentalmente, para a agricultura do Paraná e Centro-Oeste, e em parte, para a economia urbana de SP, que crescia com a industrialização. A partir da "Crise de 29", o agro paulista atraiu importantes fluxos de trabalhadores rurais de Minas Gerais e do Nordeste. Entre 1940 e 1970, migraram para o estado de São Paulo, 2,5 milhões de brasileiros não paulistas (81\% dos quais, de MG e do NE), consolidando o Estado como principal receptor da emigração nacional;

- a colonização do norte do Paraná e do oeste de Santa Catarina, que se estende até a década de 1960, com base em agropecuária diversificada e caracterizada pela pequena e média propriedade; 
- fato semelhante, mas de menor impacto, ocorreu com o sul de Goiás e ainda em menor escala no sul do atual Mato Grosso do Sul, para o que contribuiu a política federal da "Marcha para o Oeste" e mais tarde a construção de Brasília e da Belém-Brasília.

Esses novos espaços - no CO, no PR e em SC - que constituíram uma "fronteira exuberante", com produção eficiente e melhor distribuição de renda, receberam grandes fluxos migratórios de habitantes do NE, de MG, do Rio Grande do Sul e de São Paulo: os que se dirigiram ao Sul somaram (em 1.000 pessoas), respectivamente, cerca de 400, 500, 450 e 700; os fluxos em direção ao CO foram ainda modestos, predominando os de paulistas (cerca de 200).

- a grande ocupação no Maranhão e no norte de Goías (atual norte do Tocantins), e mais ao fim deste período, no sudeste do Pará, que se pode caracterizar como uma "fronteira de pobres", dada a questão fundiária local, a precariedade de sua agricultura e as perversas relações sociais de produção. Este espaço constituiu, claramente, uma perversa manifestação do fenômeno da agricultura itinerante de que falou Furtado (1972). Para esta fronteira acorreram grandes fluxos de nordestinos não residentes (cerca de 400.000) no MA. Com a continuidade da itinerância dessa agricultura, as levas de nordestinos (maranhenses ou não) migraram também para o atual norte do TO e o sudeste do PA; foram cerca de 100.000 pessoas.

Há que ter presente, no caso da agropecuária, que, à medida que ela se moderniza e cresce, embora expulse parte de seu emprego direto, gera outros empregos indiretos urbanos, seja na agroindustrialização ou na indústria que lhe fornece bens de produção, seja em várias atividades produtoras de serviços. É isto que explica, por exemplo, a notável rede urbana gerada pela cafeicultura paulista antes de 1929, e a do norte do PR, durante a "colonização" agropecuária que ali se deu entre 1925 e fins da década de $1960 .^{2} \mathrm{O}$ oposto disso se deu na ocupação do MA, do antigo norte de GO (atual TO) e do sudeste do PA, no período posterior à década de 1940 .

Em termos regionais, a demografia sofreu forte influência dos fluxos migratórios, cujo total nacional passa de 2,7 milhões em 1940 para 11,9 milhões em $1970 .^{3}$ Entre $1940 \mathrm{e}$ 1970 (em 1.000 pessoas), as entradas acumuladas em São Paulo passaram de 726 para 3.185; no Paraná, passaram de 214 para 2.467 e no Rio de Janeiro, de 602 para 2009.

A população brasileira, que entre 1920 e 1940 crescera à modesta taxa média anual de 1,5\%, com as transformações econômicas e sociais que ocorreram após 1930, acelera seu crescimento, para 2,3\% em 1940-1950 e para cerca de 3\% em 1950-1970. Mas a população urbana cresceria muito mais: 3,8\% em 1949-1950, 5,3\% em 1950-1960 e 5,1\% em 1960-1970.

Durante todo esse período, as taxas nacionais foram ligeiramente superadas pelas paulistas. Contudo, a urbanização gerada pela cafeicultura em São Paulo - e sua notável rede urbana - era relativamente maior do que a nacional: foi acelerada com o aumento de seus fluxos imigratórios e com parte de seu próprio êxodo rural, com o que, em 1940, as taxas de urbanização do Brasil e de São Paulo eram respectivamente $31 \%$ e 44\%, distância que aumenta em 1970, para 56\% e 80\%. Cabe ainda apontar que, se excluirmos São Paulo e o Rio de Janeiro, o restante do Brasil apresentaria, naqueles anos, as taxas de $25 \%$ e $45 \%$ apenas.

A estratificação das cidades, por tamanho, também é útil para examinarmos essa evolução. Em 1920, o país tinha apenas uma cidade com mais de um milhão de habitantes, o Rio de Janeiro, e uma com mais de 500 mil, São Paulo, que só em 1940 figuraria com mais de um milhão. Em meados dos anos 1950, São Paulo (e o aglomerado que viria a
2 Sobre as redes urbanas do Brasil até a década de 1950, ver o excelente trabalho de Geiger (1963).

3 Cifras calculadas com eliminação das migrações entre as UFs das regiões NO, NE e CO. 
ser sua região metropolitana) ultrapassavam o Rio de Janeiro e sua futura RM. Na escala de 500 mil, só em 1950 teríamos uma - Recife -; em 1960 seriam cinco e seis em 1970, com o surgimento de Brasília.

Se baixada a escala para cidades entre 250.000 e 500.000 , também seria escasso seu número: apenas Salvador em 1920; mais duas (Recife e Porto Alegre) em 1940; mas em 1970 já figuravam 14, das quais 9 sediadas em SP e no RJ. Tínhamos em 1920, na escala de 100.000 a 250.000, 10 cidades (3 em São Paulo); em 1940, 18 (2 em São Paulo e 4 no Rio de Janeiro) e em 1970 elas seriam 66 (17 em São Paulo e 5 no Rio de Janeiro).

Assim, a maior concentração urbana no período se restringe a São Paulo, Rio de Janeiro, Brasília e a algumas capitais estaduais. Nova Iguaçu, na baixada fluminense, município agrícola até meados da II Guerra e depois, predominantemente, cidade-dormitório do Rio de Janeiro, fazia parte desse grupo, com seus 727.000 habitantes.

Contudo, o que predomina em todos os estados brasileiros é a grande presença de cidades menores, notadamente abaixo de 100.000 habitantes. Mas isso, longe de representar uma identidade, oculta, na verdade, uma dura realidade de diferenciação regional de crescimento, renda, ocupação e melhor nível de vida.

O exame da estrutura do emprego mostra o mesmo processo: em 1940, Brasil e São Paulo empregavam, respectivamente, $67 \%$ e $58 \%$ da População Economicamente Ativa (PEA), nas atividades primárias, $13 \%$ e $17 \%$ na indústria e os serviços ocupavam apenas $20 \%$ e $25 \%$. Em 1970 , os mesmos dados eram de $44 \%$ e $20 \%$, $18 \%$ e $31 \%$ e $38 \%$ e $49 \%$, mostrando o grande distanciamento entre aquelas estruturas ocupacionais. Contudo, o agregado Brasil - (São Paulo + Rio de Janeiro) em 1970 tinha ainda a seguinte estrutura: $57 \%$ em primários, $12,5 \%$ no setor industrial e apenas $30,5 \%$ em serviços. O país estava se transformando e urbanizando em "alta velocidade", contudo, as reduzidas bases periféricas de industrialização e urbanização impediam que a evolução regional fosse tão avançada quanto a que se dava em São Paulo.

Concluindo este subperíodo, cabe dizer que, a despeito da velocidade do processo de urbanização, notadamente nos estados mais industrializados, há que entendê-lo como de uma urbanização suportável, dada a existência de mecanismos de assentamento e acomodação das camadas de baixa renda, em termos de possibilidade de uma periferização ainda próxima aos centros urbanos, acesso a lotes baratos ou ocupação de áreas até então não disputadas com o capital mercantil, como morros, alagados e outras áreas ruins ou inapropriadas.

Por outro lado, e a despeito dessa velocidade de crescimento, como o emprego urbano cresceu aceleradamente, a fiscalidade estadual e municipal também cresceu, não na mesma proporção da expansão urbana, mas mesmo que de forma ainda parcial elevou o gasto público urbano e a oferta de serviços sociais, amenizando o drama social que em um futuro próximo surgiria.

4 Como base deste tópico temos Cano (2008).

\section{A DÉCADA DE $1970^{4}$}

Contudo, a velocidade e o adensamento urbano - notadamente em São Paulo e no Rio de Janeiro -, amplificaram as tensões sociais, desencadeando, no plano político, uma crescente massa de reivindicações que se consubstanciaram nas chamadas "Reformas de Base" (agrária, urbana, tributária, financeira, educacional, da saúde e outras), com fortes conteúdos de justiça social e nacionalismo. Essa efervescência, entretanto, atemorizou suas conservadoras elites, conduzindo esse caudal para o golpe militar de abril de 1964. 
A ditadura fez algumas das reformas, não como as sonhávamos, e sim com um estrito sentido capitalista praticamente desprovido do social. Destaquemos as duas principais reformas econômicas:

- a tributária, que modernizou a estrutura fiscal ao mesmo tempo em que centralizou, na órbita do governo federal, uma massa crescente de recursos diminuindo a participação dos estados e municípios, o que afetaria sobremodo seus potenciais de gastos e, portanto, de atendimento das crescentes demandas sociais;

- a financeira, instituindo a correção monetária, ampliando os canais de financiamento para os segmentos de bens de consumo duráveis e de capital e para a modernização da agricultura de exportação.

Essas duas reformas ampliaram muito a capacidade federal de gasto e investimento público, com o que a política macroeconômica, a partir de 1966-67 pode retomar e acelerar o crescimento e a diversificação da economia. As novas bases de financiamento de médio e longo prazos deram maior apoio ao investimento e à produção privada. $\mathrm{O}$ investimento total, como porcentagem do Produto Interno Bruto (PIB), atingiria no auge do período (1970-74) cerca de 25\%.

As políticas sociais foram em certa medida negligenciadas, principalmente, a do salário mínimo, que continuaria a sofrer maiores quedas reais. A agrária foi transformada em um simulacro, para, justamente, não fazê-la. Exemplo notável foi a construção da Rodovia Transamazônica, instrumento para agilizar as migraçōes nordestinas rumo ao Noroeste, com o que se esvaziava a pressão fundiária no Nordeste. A política urbana limitou-se às novas formas de financiamento de habitação e saneamento básico (Poupança, Fundo de Garantia por Tempo de Serviço e Banco Nacional de Habitação), com o que a política habitacional expandiu sobremodo a construção residencial, e isto acomodava o problema do emprego e cooptava politicamente a população beneficiada com esse programa.

A questão regional, para a qual havia sido implantada em 1960 uma Política de Desenvolvimento Regional com incentivos econômicos para o Nordeste, teve, a partir de 1967, seus recursos direcionados também para o Noroeste e, em seguida, dispersados pelo surgimento de novos programas, a maior parte dos quais para todo o território nacional, como os investimentos em turismo, pesca, reflorestamento, mercado de capitais e indústria aeronáutica.

A intensidade do crescimento entre 1967 e 1980 "compensou" esses constrangimentos: a queda do salário mínimo foi atenuada pelo excepcional crescimento do emprego urbano, que elevou o salário médio e dispersou a estrutura salarial. A dispersão dos recursos financeiros regionais do Noroeste e Nordeste foi compensada pela desconcentração regional do investimento, pois o aprofundamento e diversificação imprimidos à industrialização obrigavam a uma utilização mais intensa das bases regionais de recursos naturais (terras, água e minérios). ${ }^{5}$ Isso também obrigou a uma forte desconcentração regional da infraestrutura energética, de comunicações e de transporte.

A taxa média anual do PIB entre $1970-1980$ foi de $8,7 \%$ para o Brasil $(8,2 \%$ para São Paulo). A agropecuária cresceu a 3,8\%, alta, se confrontada com a demográfica, que foi de $2,5 \%$. Os serviços, impulsionados pela industrialização, cresceram a $8 \%$ e a indústria de transformação a 9\% (8,1\% em São Paulo e 10,2\% no agregado Brasil-São Paulo).

A participação da periferia nacional aumentou a desconcentração industrial, passando de $0,8 \%$ para $2,4 \%$ no Noroeste, basicamente explicada pela implantação da Zona Franca de Manaus; o Nordeste saltou de 5,7\% para 8,1\%, recuperando parte das perdas sofridas no período anterior; Minas Gerais, foi de 6,5\% para 6,7\% e o Espírito Santo,
5 Implantação ou expansão de celulose e papel, metais não ferrosos, química, álcool de cana, petroquímica e outros. 
de $0,5 \%$ para $0,9 \%$, foram os principais beneficiados. Os maiores perdedores foram São Paulo (cai de $58,1 \%$ para $53,4 \%$ ) e o Rio de Janeiro (de $15,7 \%$ para 10,6\%). A desconcentração industrial em São Paulo também teve um vetor interno: a participação da Região Metropolitana de São Paulo no total nacional cai de 43,5\% para 33,6\% enquanto a do interior sobe de 14,7\% para 19,8\%, desenvolvendo, também nesse espaço estadual, a urbanização e a produção de serviços.

A modernização e expansão da agropecuária se concentraram mais em São Paulo e região Sul, e em menor escala no Centro-Oeste. Seus principais produtos foram a soja, o trigo, a laranja, a cana-de-açúcar e as carnes. Ressalte-se que a expansão no Paraná deu-se nas áreas em que antes predominava a pequena e média propriedade, transformando as estruturas produtivas e da propriedade, resultando na expulsão, nessa década, de paranaenses (predominantemente rurais), do equivalente a 22,8\% de sua população de 1970. A ocupação do Noroeste se iniciava, notadamente no Pará, em pecuária e cultivos tradicionais.

Os fluxos migratórios inter-regionais saltaram de 12 milhões de pessoas em 1970 para 16,5 milhões em 1980. As maiores saídas continuaram a ser de nordestinos (2,3 milhôes), paranaenses (1,6 milhôes) e mineiros (800 mil). A principal área receptora foi São Paulo, com o recorde de 2,8 milhões de pessoas (cerca de 1,5 de nordestinos, 0,6 de mineiros e 0,55 de paranaenses, além de outros). O Rio de Janeiro diminuía sua recepção, para cerca de 500 mil, mas aumentava sua própria expulsão, para cerca de 180 mil.

A fronteira Noroeste receberia 650 mil pessoas (260 mil do Nordeste; de Minas Gerais, Paraná e Centro-Oeste-DF, 90 mil de cada e outros). A do Centro-Oeste-Distrito Federal, recebeu 500 mil: 180 mil do Paraná; do Nordeste e de São Paulo, 100 mil de cada, além de outros. Brasília continuou sendo importante receptor, acusando entrada de 380 mil pessoas.

A taxa média anual de crescimento demográfico caíra de 2,9\% nos anos 1960 para 2,5\% nos 1970, mas o acréscimo absoluto da população foi maior: (23 milhões contra 26). A da população rural, que já fora pequena nos anos 1960 (0,7\%), torna-se negativa nos 1970 (-0,5\%). A taxa de crescimento da população urbana também caiu nos mesmos períodos de 5,2\% para 4,4\%, mas o acréscimo absoluto foi ainda maior: 28 milhóes nos anos 1970 contra 21 nos anos 1960.

A taxa de urbanização para o total do Brasil sobe de 55,9 \% em 1970 para 67,3\% em 1980, mas enquanto as áreas mais industrializadas (SP e RJ) apresentavam cifras que ultrapassaram os $80 \%$ para cerca de $90 \%$; o NO $(51,7 \%)$, NE $(50,6 \%)$ e CO-DF (pouco mais de 60\%) eram as áreas menos urbanizadas do país.

A aceleração do crescimento industrial, induzindo fortemente a expansão diversificada dos serviços fez com que, pela primeira vez na história recente do país, a taxa média anual de crescimento do emprego da PEA não agrícola $(6,16 \%$, contra 4,62\% na década anterior) superasse a taxa de crescimento da população urbana (4,4\% contra $5,2 \%$ da década anterior). Isso certamente representou um enorme amortecedor de tensóes sociais e possibilitou ganhos reais nos salários médios, dada a grande pressão no mercado urbano de trabalho.

A estrutura da PEA empregada mostra o positivo efeito da industrialização: para o Brasil, o emprego agrícola cai de $44 \%$ para $30 \%$, o industrial sobe de $18 \%$ para $25 \%$ e o de serviços, de $38 \%$ para $44,5 \%$; para SP, as cifras correspondentes foram de $20 \%$ para $11,5 \%$, de $31 \%$ para $39 \%$ e de $49 \%$ para $49,5 \%$. O agregado Brasil (SP+RJ) mostrava ainda elevado emprego agrícola $(41,3 \%)$ e baixo terciário (apenas 38,7\%) embora tivesse duplicado a participação do industrial que passa de $12,5 \%$ a $20 \%$. 
Em termos de tamanho de cidades, a urbanização do período concentrou-se um pouco mais, embora com menor intensidade. Na década de 1960, a população total cresceu 33\%, mas as 10 maiores cidades (7 delas com mais de 500 mil habitantes) cresceram em média $54 \%$, e o conjunto das demais cresceu apenas 29\%, as quais perfaziam $84 \%$ da população. Na década de 1970 , enquanto a população total cresceu $27,8 \%$, as 11 maiores cidades (aquelas 10 mais Brasília), cresceram em média 39,5\% e a média das demais 25\%, perfazendo agora $79 \%$ da população total.

De 2 cidades com mais de 1 milhão de habitantes em 1960, passamos a contar com 5 em 1970 e com 10 em 1980. Esse movimento intensificou ainda a conurbação com municípios vizinhos, que seria o processo de transmissão intermunicipal de todas as mazelas e efeitos nocivos dessa descontrolada urbanização (a urbanização explosiva). O aumento dessas aglomerações urbanas ensejou sua transformação em regiões metropolitanas, institucionalizadas a partir da década de 1970, mas sem contar com fiscalidade própria. Em 1970, as 9 RMs (São Paulo, Rio de Janeiro, Belo Horizonte, Recife, Salvador, Fortaleza, Belém, Porto Alegre e Curitiba) perfaziam 23,7 milhões de habitantes e em 1980, 34,4 milhôes ou o equivalente a $28,8 \%$ da população total do país.

A urbanização acelerada gerou uma série de efeitos complexos. A periferização de populações de média e baixa renda foi a tônica desse processo, para o que muito contribuiu a própria política habitacional do regime militar. Esse efeito estimulou o aumento da especulação imobiliária, encareceu sobremodo os custos da infraestrutura urbana e piorou a qualidade de vida urbana. ${ }^{6}$ Além disso, o elevado encarecimento da moradia e a omissão e corrupção política dos órgãos públicos amplificou também a ocupação de espaços impróprios para assentamentos humanos, como morros, encostas, alagadiços e outros.

Por outro lado, conurbação, aglomeração e metropolização superdimensionaram vários problemas de ordem municipal e de solução local, multiplicando seus tamanhos e custos, tornando-os, assim, problemas regionais, estaduais ou mesmo federais. Isso agravaria ainda mais essa situação, diante da concentração de receita fiscal na órbita federal e do aumento desses problemas. É o que passou a ocorrer com o tratamento do lixo, da questão da água e do esgoto, do transporte coletivo etc.

\section{O PERÍODO PÓS 1980: NOVAS DETERMINAÇÕES SOBRE OS PROCESSOS DE DESENVOLVIMENTO REGIONAL E DE URBANIZAÇÃO?}

As principais mudanças, em seu patamar mais geral, ocorreram a partir das novas bases da Política Econômica Nacional, resultando em alterações radicais no ritmo e na forma de crescimento econômico do país, mudando significativamente nossas estruturas produtivas, de emprego e de relações internacionais. Elas também impactaram sobre as estruturas sociais e políticas, e causaram importantes alterações no processo de integração e desenvolvimento regional e no próprio processo de urbanização.

Não tratarei aqui da questão macroeconômica nacional, já examinada pela ampla literatura atual, mas embora não vá tratar dela, adianto que sua análise geral está hoje parcialmente comprometida pelas muitas mudanças espaciais que ocorreram na economia. Dito de outra forma, essas mudanças mais gerais e de caráter nacional geraram efeitos espacialmente muito diferenciados. Corre-se hoje o risco de falarmos em "Brasil", tomando como dados para análise, simples médias estatísticas nacionais, que
6 Sobre os efeitos da urbanização do período, ver Cano (2011). 
encobrem movimentos e determinações espaciais muito mais diversos do que os que se observavam antes de 1980.

Como primeiro ponto para essa Agenda de Pesquisa, cabe estabelecer uma periodização, de caráter nacional, que distinga as grandes linhas do período e suas maiores modificaçóes. Assim, o período como um todo será seccionado em três: o da década de 1980; o do período 1989-2003 e o de 2003-2010. Vejamos os principais fatos marcantes de cada subperíodo.

I980-I989: A “Década Perdida”

A crise, que vinha desde 1976, se agrava a partir de 1979, devido à brutal elevação internacional dos juros, tornando a dívida externa impagável, desestruturando as finanças públicas, desencadeando um processo inflacionário e de estagnação. A crise só não foi pior graças à forte expansão das exportações, que cresceram 71\% entre 1980 e 1989, em que pese a queda dos preços internacionais de produtos básicos.

A recessão conteve as importações, que cresceram apenas $24 \%$, com o que geramos na década, US $\$ 97$ bilhóes de saldos comerciais, incapazes, contudo - frente ao que remetemos de juros (US\$87 bilhōes) além de outros pagamentos -, de evitar o aumento da dívida externa, a qual, entre o início e o fim da década saltou de 64 para 115 bilhões de dólares.

O elevado impacto orçamentário dos juros da dívida pública contaminou também os governos subnacionais, que exacerbaram suas dívidas e também sofreriam os percalços decorrentes de seu crescente serviço. Esse forte desequilíbrio financeiro do estado restringiu suas ações no plano nacional e regional debilitando não só o gasto público, mas também o investimento privado, notadamente o industrial, atingindo, principalmente, o núcleo da dinâmica industrial - o parque produtivo de São Paulo -, que estagnou, diminuindo os efeitos dinâmicos para a desconcentração industrial regional.

O crescimento médio anual do PIB foi medíocre, tanto para o Brasil $(2,2 \%)$ como para São Paulo (1,5\%). O setor agropecuário continuou obtendo taxas (3,2\%) de crescimento em torno de sua trajetória anterior, graças ao programa energético do álcool de cana e à expansão das exportações agrícolas e agroindustriais, em parte decorrentes da expansão da fronteira no $\mathrm{CO}$.

A indústria de transformação, o setor antes mais dinâmico, teve desempenho ainda pior, pífio, de 0,9\% para o Brasil e ainda mais baixo para SP (0,2\%), sendo de 1,6\% para o agregado Brasil-SP. A continuidade da diversificação industrial parou, com sua estrutura regredindo, pois os segmentos de bens de produção e de consumo durável foram mais afetados do que os de bens de consumo não durável. Demos um passo atrás na evolução industrial, em um período em que o capitalismo mundial acelerava sua reestruturação produtiva.

A crise industrial só não foi pior graças aos segmentos mais vinculados às exportações agroindustriais, minerais e de insumos básicos, além dos vinculados à questão energética, como álcool de cana-de-açúcar e petróleo, este decorrente da forte expansão da extração na Bacia de Campos, no RJ.

A desconcentração industrial prosseguiu, com SP perdendo 3,2 pontos percentuais na produção nacional do setor. Adverte-se, porém, que se no período 1980-1985, a participação paulista caiu de $53,4 \%$ para $51,9 \%$ isso se deu mais porque a taxa negativa de crescimento de SP foi maior do que a do Brasil. Em 1989 a participação cairia um pouco mais, para 50,2\%, não por um crescimento satisfatório da periferia, mas sim porque a 
taxa positiva de crescimento de SP foi medíocre, e abaixo da reles taxa verificada para o conjunto do país. Desconcentração espacial, em tempo de crise profunda, tem sentido muito diverso da que ocorre quando se dá crescimento normal ou alto. No período, ela foi espúria, um resultado meramente estatístico.

Até mesmo o setor de serviços cresceu pouco (médias anuais de 3,1\% para o Brasil e 2,2\% para SP) e sua expansão nesse período decorre não só da continuidade da desconcentração dos outros setores produtivos. Uma explicação para isso é a de que o êxodo rural cresceu muito, diminuindo a população rural, entre 1980 e 1991, em 2,8 milhões de habitantes. Mas o fraco desempenho industrial fez com que seu emprego aumentasse apenas $19 \%$, enquanto a população urbana aumentava $38 \%$, pressionando pelo aumento da oferta de vários serviços.

O Censo de 1991 mostra que a diferença entre a PEA total e a ocupada atingiu 3,2 milhōes de pessoas, cifra muito acima da verificada pelo Censo de 1980, no qual a não ocupação era de 964 mil pessoas. Assim, além do aumento da desocupação aberta, também aumentou o desemprego urbano oculto. A "válvula de escape" foi, como de costume, o emprego do terciário, que passou de 18,8 milhôes em 1980 para 29,7 milhôes em 1991, já dando mostras de precarização do mercado de trabalho e expansão da economia informal.

O setor de serviços, entre 1980 e 1991, foi responsável por 83\% do aumento do emprego, gerando 10,9 milhões de novas ocupações, das quais sobressaíam 1,2 milhões de empregados domésticos remunerados e 1,7 milhōes de outros empregos com predomínio de autônomos e outros serviços precários e forte queda do rendimento médio do trabalhador.

A crise afetou profundamente o fluxo migratório inter-regional: a média anual entre os Censos de 1980 e 1991 diminuiu 40\% em relação à da década de 1970 e as entradas médias em SP sofreram queda de $65 \%$. O que atenuou esse movimento foi a continuidade da expansão da fronteira agrícola no $\mathrm{NO}$ e CO, o melhor desempenho da agricultura nordestina e a forte expansão urbana ocorrida nessas três regiōes.

A taxa média anual (1980-1991) do crescimento populacional caiu ainda mais, dos $2,48 \%$ da década anterior para 1,93\%, mas as regióes NO e CO-DF apresentavam taxas pouco acima de $3 \%$, graças à atração da fronteira agropecuária. A da população urbana também caiu de $4,44 \%$ para $2,97 \%$, em proporção similar nas demais regiões, salvo no NO $(5,4 \%)$ e no CO-DF $(4,8 \%)$. Mesmo assim, a taxa de urbanização subiu expressivamente, de 67,3\% para 75,6\%, com um grande diferencial entre o NO e NE (com cerca de $60 \%$ ) e SP, RJ e DF (acima de 93\%).

O número de cidades acima de um milhão de habitantes passou de 10 para 12 (com a inclusão de Belém e Manaus), enquanto o das acima de 500.000 e abaixo de um milhão passaram de 8 para 13 (das quais 6 fora de SP e RJ), e as de mais de 250.000 e menos de 500.000, de 24 para 40 (das quais, 23 fora de SP e RJ).

Período 1989-2003

Na década de 1990, o receituário neoliberal implicou na submissão consentida dos países subdesenvolvidos à Nova Ordem, representada pelos preceitos contidos no chamado Consenso de Washington, com o que abdicamos de nossa soberania nacional, no desenho, implementação e manejo da política econômica. ${ }^{8}$

Esse Consenso está assentado para atender a duas ordens de questôes: a financeira e a produtiva. A primeira, dada a crise financeira internacional, que explicitou a supremacia do capital financeiro (financeirização da economia) sobre as outras formas de capital,
8 Para uma descrição dessas reformas e a análise de seus efeitos na América Latina e Brasil, ver Cano (2000), que apresenta, inclusive ampla bibliografia sobre o tema nessa região. 
9 Várias antigas estatais como a Companhia Vale do Rio Doce - tinham positiva ação sobre diversas partes do território nacional, agindo muitas vezes como verdadeiros agentes de desenvolvimento regional. Com a privatização essas atitudes foram sumariamente reduzidas.

100 gasto com juros passou a ser de cerca de $8 \%$ a $9 \%$ do PIB, estrangulando as finanças públicas e restringindo o crédito ao setor privado, que se reduziu, até 2003, a um volume em torno de apenas $22 \%$ do PIB. impondo a quebra da soberania nacional de nossos países, para liberar seu movimento internacional na busca incessante da valorização. A segunda, da reestruturação produtiva e comercial feita pelas grandes empresas transnacionais (ETs), em suas bases localizadas nos países desenvolvidos, que também exigiria, na década de 1990, reestruturações semelhantes em suas bases localizadas nos subdesenvolvidos. Isto foi reforçado pela voracidade do capital estrangeiro na compra de empresas públicas e privadas nacionais, debilitando ainda mais nossa já precária soberania nacional.

Destas duas ordens derivaram os objetivos para impor um conjunto de reformas institucionais liberais, que constituem um todo articulado para permitir a funcionalidade do modelo neoliberal. Elas, resumidamente, compreendem:

- desregulamentação dos fluxos financeiros internacionais, para adequar nossa economia aos interesses do capital financeiro internacional;

- a reforma do sistema financeiro nacional para compatibilizá-lo com o sistema internacional;

- a abertura comercial, potenciada pela grande valorização do câmbio, reduziu fortemente os custos dos importados, debilitou as exportaçôes, e gerou grandes deficits comerciais e de serviços. Constituiu ainda forte apoio à política anti-inflacionária;

- flexibilização das relações trabalho-capital, para diminuir ainda mais o custo do trabalho, adequar contratos ao novo timing da tecnologia e debilitar estruturas sindicais;

- reformas previdenciárias, para criar mais um importante segmento para o mercado financeiro e abrir maior espaço no orçamento público para os juros das dívidas públicas interna e externa;

- reforma do estado nacional, para desmantelar suas estruturas, diminuir seu tamanho e sua ação, eliminar vários órgãos públicos, dispensar funcionários e reduzir seus salários reais, privatizar ativos públicos ${ }^{9}$ e desmantelar os sistemas de planejamento e de regulamentação;

- os estados subnacionais (governos estaduais e prefeituras) que também estavam com sua fiscalidade debilitada e fortemente endividados, foram obrigados a negociar suas dívidas com o governo federal, entre 1996 e 1998, comprometendo por 30 anos parte de suas receitas com o pagamento compulsório de amortizaçóes e juros, reduzindo fortemente suas capacidades de gasto, em especial de investimentos.

Esse quadro foi complementado pela nova política de estabilização, implantada entre fins de 1993 e junho de 1994, bem-sucedida, mas que teve como lastro uma elevada valorização da moeda nacional ante o dólar e um ciclópico crescimento da dívida pública interna, inflada por elevados juros reais.

Ocorre que a dinâmica de funcionamento desse novo "modelo", à medida que o PIB cresce, aumenta aceleradamente as importações e outros gastos externos, exigindo altos, crescentes e persistentes fluxos de capital estrangeiro, forte aumento das dívidas externa e interna, contaminando as contas públicas, dados os elevados juros. ${ }^{10}$

É fato que houve importante entrada de capitais como Investimento Direto Estrangeiro (IDE), mas a maior fração dele destinou-se a comprar empresas públicas e privadas nacionais, predominantemente na área de serviços (distribuição de energia, transportes, telecomunicações, instituições financeiras etc.). Com isso, tais empresas passaram a remeter juros e lucros ao exterior, tornando-se consumidoras líquidas de divisas e o país ampliou sobremodo seus gastos com serviços importados.

Contudo, a provável deterioração do balanço de pagamentos e das contas públicas, sensibiliza as finanças internacionais, freando a entrada de capital, e com isso gerando uma 
crise cambial e uma recessão. ${ }^{11}$ Com isto, o câmbio se desvaloriza, as importações se contraem e as exportações crescem. Porém, a taxa de crescimento do PIB cai, só retomando patamares mais altos, quando a "festa" de gastos internacionais pôde ser reiniciada.

Dessa forma, o crescimento só pode ser ciclotímico e baixo, resultando em uma taxa média anual tão medíocre quanto a observada na década anterior: entre 1989 e 2003 a taxa do PIB foi 2,3\% para o Brasil e 1,5\% para SP. O investimento despencou, de cerca de $25 \%$ no final da década de 1970 , para cerca de $18 \%$ : 1) o público, porque não há nem política de desenvolvimento, nem, muito menos, recursos no orçamento público; 2) o privado, dada a incerteza do movimento da economia e os elevados juros internos. Também a estrutura do investimento mudou com predomínio do setor de serviços e de construção civil, e em detrimento da indústria.

A estrutura produtiva também mostra fortes danos: diminuiu o peso da indústria de transformação, que cai, para o Brasil, de 30,8\% em 1989 para 18,1\% e em SP de 40,9\% para 35,0\%; a agropecuária passaria, para o Brasil, de 9,1\% para 7,4\% (em SP, subiria de $3,5 \%$ para $7,7 \%$ ); o setor de serviços aumentaria, no Brasil, de $50,3 \%$ para $64,8 \%$ e em SP, de $48,2 \%$ para $48,5 \%{ }^{12}$

Assim, as restriçōes externas e internas ao crescimento foram aumentando ao longo do período inibindo o investimento, pelas razões já apontadas. É preciso também lembrar que a crescente contaminação dos juros no orçamento público leva a novos e crescentes cortes do gasto corrente, inclusive em áreas sociais.

Ainda assim, após 1999, graças à desvalorização cambial e ao início do "efeito China" as exportaçōes (principalmente de commodities) cresceram mais e as importaçōes se contraíram, fazendo com que exportações e consumo liderassem o pífio crescimento do período.

Vale notar que em 2003, a despeito da negociação e em que pese o elevado comprometimento compulsório (de $9 \%$ a 13\%) da receita corrente líquida, dos 27 estados, a relação dívida líquida/receita líquida corrente era pouco menor que 1 em apenas três deles. No entanto, em quinze deles, ela era superior a 1 e em oito, superior a 2, mostrando a enorme dificuldade de sua liquidação na maioria das unidades federadas.

\section{A QUESTÃo REgIONAL NO PERÍODO}

O período foi fértil em discussões sobre a questão regional brasileira, em especial frente às vicissitudes da crise do Estado, da globalização e dos efeitos das políticas neoliberais. ${ }^{13} \mathrm{Com}$ a deterioração fiscal e financeira dos entes públicos subnacionais, os investimentos públicos estaduais e municipais também caíram. Com a crise federal, feneceram as políticas nacionais e regionais de desenvolvimento, crescendo então a famigerada Guerra Fiscal envolvendo praticamente todas as UFs e muitos municípios de um mesmo estado, com intuito de atrair investimentos de uma área para outra. ${ }^{14}$ Lembremos, porém, que a Guerra Fiscal já se inicia em fins da década de 1970, sendo seus dois mais notáveis casos a transferência de grande parte da produção de aparelhos de "som e imagem" para a Zona Franca de Manaus (ZFM) e da implantação da Fiat em Minas Gerais.

Ao longo desse processo, aumentou também a deterioração técnica, política e econômica dos órgãos regionais de fomento (Sudam e Sudene) que acabaram por ser extintos em 2001 e só recriados em 2007, porém em bases precárias.

Abandonando a opção de uma verdadeira Política de Desenvolvimento Regional, o governo federal criou em 1995, a política dos Grandes Eixos, ${ }^{15}$ os quais seriam vetores
11 De 1995 a 2002, o deficit em transações correntes acumulou a fantástica cifra de US\$199 bilhões; nossa dívida externa saltou de US\$150 bilhões para US\$235 bilhões e nosso passivo externo atingiu cerca de US\$400 bilhões. Isso nos levou às crises cambiais de 1999 e 2003.

12 Os dados de SP são os das Contas Regionais, na base de 1985. Se mudadas para a nova metodologia com a base em 2002, as cifras resultantes para 2003 são simplesmente incompreensíveis, principalmente a da agropecuária, que passa a ser de apenas $2,2 \%$, enquanto a da indústria de transformação passava a $23,9 \%$ e os serviços a $65,9 \%$.

13 Entre os principais trabalhos publicados sobre 0 assunto, cabe citar: Affonso e Silva (1995), Araújo (1999 e 2000), Cano (2007b) e Diniz (2005). Nos aspectos da inovação frente à questão regional, Galvão (2004) faz uma profícua discussão sobre as políticas regionais da União Europeia.

14 Sobre a Guerra Fiscal, ver Cavalcanti e Prado (1998) e Silva (2001); e principalmente a pesquisa mais atual, a tese de doutorado de Cardoso (2010).

15 Para uma crítica à política dos Grandes Eixos, ver Galvão e Brandão (2003). Para a questão do Poder Local, ver Brandão (2003). 
16 Eles foram suspensos pelas Constituições de 1937 e de 1967, ambas em períodos ditatoriais, que além disso recentralizaram na União a maior parte da receita fiscal do país.

17 Além da criacão desses Fundos, foi também incluída na Carta, a obrigatoriedade da distribuição regionalizada dos recursos alocados no Plano Plurianual de Investimentos.

18 Ver legislação específica nos sites da Receita Federal (IR) e do Ministério da Integração Nacional. Da ampla bibliografia sobre a matéria, ver: Bercovici (2003), CarvaIho (2001), Mahar (1978) e PIMES (1984, v. 3). ligando zonas produtivas a portos de exportação, e receberiam grandes investimentos para aumentar a eficiência e competitividade exportadora. Contudo, eles apenas ligariam pontos de origem-destino, e pouco ou nada fariam em prol dos maiores espaços regionais em que estivessem inseridos, e nem tratavam dos problemas urbanos e sociais das cidades maiores por eles envolvidas. Mais de dois terços desses investimentos viriam do setor privado, mas, dados os juros escorchantes e a incerteza pelo pífio crescimento, "ficaram ao largo", retardados e aguardando dias melhores.

Esse esvaziamento das políticas e dos recursos para o desenvolvimento regional deu azo à disseminação, junto à Academia e aos órgãos públicos que tratam da matéria, "novas e modernas" ideias, como as do poder local, da região (ou cidade) competitiva, submetendose a verdadeiros leilóes de localização industrial promovidos por empresas de grande porte (geralmente transnacionais), transferindo dinheiro de pobres para milionários, e fomentando a localização pelo subsídio e pelo trabalho periférico ainda mais precarizado e mais barato. Cabe acrescentar que, nesse movimento, as antigas ideias de planejamento e desenvolvimento foram substituídas pelas políticas dos APLs (Arranjos Produtivos Locais), nome inventado no Brasil, para substituir, com fragilidade, os de cluster ou dos verdadeiros distritos industriais.

No que se refere aos recursos públicos constitucionais, eles foram restaurados pela Constituição de 1988 (A 159), porém em outros níveis: ${ }^{16}$ 3\% não sobre a arrecadação total, como antes, mas apenas sobre o Imposto de Renda (IR) e Imposto de Produtos Industrializados (IPI); criou, para isso, Fundos Constitucionais para as três regióes beneficiadas: Fundo Constitucional de Financiamento do Centro-Oeste (FCO), com 0,6\%, Fundo Constitucional de Financiamento do Norte (FNO) com 0,6\% e Fundo Constitucional de Financiamento do Nordeste (FNE) com 1,8\%. ${ }^{17}$ Essas dotações representavam muito pouco, se comparadas com os respectivos PIBs regionais: em 2003, equivaliam a $0,5 \%$ para o $\mathrm{CO}$ e $0,8 \%$ para o $\mathrm{NO}$ e para o NE. Se tivesse sido mantido o que dizia a Constituição de 1946, essas cifras seriam muito maiores, de $11,2 \%$ para o NO e de 5,4\% para o NE.

Quanto aos incentivos fiscais, que consistem em isenções parciais de imposto de renda, para aplicação em investimentos privados regionais aprovados pela Sudene ou pela Sudam, exigiam uma contraparte de recursos pelo investidor privado. Esse subsídio perfazia cerca de 40\% do investimento entre 1965 e 1970, baixando depois para cerca de 25\%. Para o NO, os incentivos representaram cerca de 5,7\% do PIB médio regional do período 1963-1970, caindo para 4,8\% na média de 1971-1975. Para o NE, embora os valores absolutos tivessem sido em média o dobro dos alocados na região NO, as cifras representaram apenas 2,1\% do PIB do NE para o período 1965-1970 e 1,8\% para 1971-1975.

Além disso, os percentuais de incentivos foram sendo reduzidos, tanto em termos de captação quanto de aplicação, com o que em 2000 seus repasses representavam, em termos dos PIBs regionais, tão somente 1,2\% para o $\mathrm{NO}$ e 0,3\% para o NE. ${ }^{18}$ Em 1997 pela Lei 9532, os fundos de incentivos fiscais (Finam e Finor) tiveram sua permanência limitada ao ano de 2013, com redução gradativa dos percentuais do incentivo.

Em 2001, foram criados dois novos Fundos de Desenvolvimento Regional (não substitutivos dos existentes), o FDA e o FDNE, com recursos orçamentários que complementariam os demais fundos. Contudo, o FDA só começou a operar em 2007 e o FDNE em 2009. O montante de recursos liberados em 2007 e 2008 para o FDA representou tão somente $0,28 \%$ e $0,16 \%$ do PIB regional, e as cifras de 2009 e 2010 foram ainda mais baixas. Para o FDNE, em 2009 e 2010 as cifras são também baixas e representariam algo como $0,07 \%$ e $0,33 \%$ do PIB do NE. Essa demora decorreu de problemas burocráticos, 
de alto custo de seus financiamentos e dos drásticos contingenciamentos e cortes orçamentários, em parte hoje atenuados.

Entretanto, a diminuição dos prazos, dos percentuais e dos recursos desses fundos foi em parte compensada graças às alterações constitucionais que reverteram parte da concentração fiscal exercida pela União. Na década de 1970, dos recursos fiscais, deduzidas e somadas as transferências intergovernamentais, a União ficava com 69\%, os estados com $22 \%$ e os municípios com $9 \%$; ao final da década de 1990 , as cifras respectivas eram de cerca de $56 \%$, 27\% e $17 \%$. Mas boa parte desse acréscimo aos entes subnacionais consiste em recursos vinculados (notadamente para a saúde e educação) e mais de caráter corrente e redistributivo que, se bem sejam sumamente necessários, limitam a capacidade de investimento.

Em termos regionais, o NO, que tinha receitas próprias mais transferências federais líquidas de cerca de $21 \%$ de seu PIB em 1970, e que havia baixado para $8 \%$ em 1980, obteria $18 \%$ em 2000 ; o NE, nas mesmas datas, passou de $11 \%$, para $8 \%$ e saltou para $22 \%$ e o CO, de $30 \%$, para $16 \%$ e para $21 \%$. O Sul e o Sudeste são regiōes perdedoras líquidas, redistribuindo frações elevadas de suas rendas tributárias paras as demais. Entre seus estados, SP é o campeão das perdas, com -17\% em 1970, -11\% em 1980 e -14\% em $2000 .{ }^{19}$ Contudo, a reformulação das dividas estaduais e municipais, imposta pelo governo federal a partir de 1995, comprometeu cerca de 13\% da receita líquida corrente dos entes endividados, fazendo com que, mesmo as regióes ganhadoras tivessem diminuído seus ganhos, e as perdedoras aumentado suas perdas, com o pagamento anual de amortizaçōes e juros: o NO, que em 2000 recebera 17,7\% do equivalente de seu PIB, tem a cifra reduzida para $16,4 \%$; o NE, de $22,2 \%$ para $20,5 \%$; o CO, de $21 \%$ para $19,9 \%$; SP, de $-14,3 \%$ para $-15,2 \% .^{20}$

Há um complexo conjunto de fatos e ações que permitiram a continuidade da desconcentração produtiva regional, como as políticas de incentivo às exportaçôes, notadamente de commodities agropecuárias, agroindustriais e minerais; à Guerra Fiscal, principalmente em termos da indústria de transformação; a execução de alguns investimentos de infraestrutura descentralizados; e os efeitos estatísticos da desconcentração industrial espúria, de que já tratei. Os resultados mais flagrantes desse processo foram, resumidamente:

- em termos de PIB total, embora todas as Unidades Federativas tenham tido taxas médias anuais positivas, o RJ $(1,2 \%)$ foi o maior perdedor, seguido por SP $(1,5 \%)$; NE, MG e RS (os três com 2,2\%) cresceram pouco abaixo da média nacional e os demais estados acima, com as maiores taxas no NO, MS e MT (os três em torno de 5\%);

- na indústria extrativa mineral, por sua especificidade, só cabe apontar os grandes ganhadores: com petróleo, o RJ, NE e ES ou com minérios metálicos, o NO;

- na agropecuária, o Sudeste perde pontos, principalmente, mais para o NO e CO-DF e um pouco para o Sul;

- na indústria de transformação, embora todos crescessem, só perderam participação no total nacional, PE, RJ e SP (a maior perda: cai de 50\% para 41\%). A dinâmica exportadora fez com que MG e ES transformassem suas estruturas produtivas predominantemente na produção de commodities industriais;

- nos serviços, tanto a desconcentração produtiva material quanto a crescente urbanização, somente RJ e SP perdem alguns pontos. Pela óptica da renda, a diversificação estrutural do setor continuou, diminuindo o peso dos segmentos mais tradicionais, como o comércio e domésticos remunerados. Contudo, pela óptica do emprego, estes segmentos estão entre os que mais cresceram, e a queda de seus pesos se deve à grande
19 Essas cifras e informações estão na Tese Doutoral de Monteiro Neto (2005, cap. 3). Ver ainda, Afonso e Varsano (2004) e Prado (2003). Sobre o endividamento estadual ver Lopreato (2002), Pinto, Cintra e Cavalcanti (2006) e Cavalcanti, Novais e Bonini (2007).

20 Ver o citado trabalho de Monteiro Neto (2005). 
21 Os absurdos incentivos recentemente criados para desconcentrar espacialmente a indústria automobilística são exemplo disso. Essas plantas montadoras foram beneficiadas pelas Leis 9440/97 e 9826/99 que concediam isenção de impostos federais ao setor. Entre os casos mais conhecidos, instalaram-se, entre 1998 e 2002, as seguintes plantas: Ford na BA; GM no RS; Mitsubishi em GO; Mercedes-Benz em MG; PeugeotCitroen no RJ; e Peugeot, Renault, Audi e Volvo no PR.

22 As principais discussões sobre o tema são as de Pacheco (1998, cap. 5) e Guimarães Neto (1997). precarização do trabalho no período e ao rebaixamento dos salários ocorridos nesses segmentos. Aliás, o Brasil ostenta hoje uma das mais altas taxas de participação do emprego doméstico no total da PEA não agrícola, de 9,8\% mas uma taxa de participação na renda não agrícola, de irrisórios $0,57 \%$ !

Seria de esperar um aumento da desconcentração produtiva agropecuária e da mineração, dada a expansão territorial do uso de recursos naturais para aquela produção, notadamente no NO e no CO-DF. Isto e mais a expansão territorial da urbanização, fez também com que houvesse uma importante desconcentração dos serviços, pelo menos dos mais comuns.

Contudo, no caso da indústria de transformação, a Guerra Fiscal, a abertura comercial e a valorização cambial enfraqueceram sobremodo a articulação da periferia com SP, a despeito de que se criaram fluxos de comércio de insumos produzidos em SP, para fornecimento às plantas desconcentradas. Mas também foram criados fluxos que substituíram a produção nacional (antes concentrada em SP) por importações, ampliando a quebra de cadeias produtivas e debilitando importantes segmentos da indústria paulista, notadamente nos setores automobilístico e no eletrônico. ${ }^{21}$

Esses fatos levaram alguns autores, em meados da década de 1990, a formularem a hipótese de que estaria ocorrendo uma fragmentação da economia nacional tanto pela quebra de alguns encadeamentos industriais intrassetoriais e intrarregionais, como pela sobredeterminação que as novas exportaçōes causavam a grande parte da periferia nacional. ${ }^{22}$ Seria desnecessário dizer que a fragmentação, se continuada e aprofundada, causaria, a longo prazo, um sério debilitamento na ordenação do desenvolvimento nacional e regional do país, constrangendo, inclusive, suas tomadas de decisóes. Voltarei a esse assunto no tópico referente ao período posterior a 2003.

\section{A QUESTÃO URBANA NO PERÍODO}

Entre 1991 e 2000, os Censos Demográficos mostram que a população cresceu à média anual de $1,6 \%$, menor do que a anterior, com o que o crescimento da renda média por habitante $(0,8 \%)$ só não foi pior do que o da década anterior. Em SP, (cuja taxa demográfica caiu de 2,1\% para 1,8\%), o crescimento da renda por habitante, que foi negativo no primeiro período passou a ser nulo no segundo. As taxas demográficas do NO $(2,8 \%)$ e do CO-DF $(2,3 \%)$ continuaram sendo as mais altas, contendo assim parte do crescimento de suas rendas médias por habitante.

As diferenças regionais de renda por habitante diminuíram, mas há que repetir a forte influência da queda do crescimento demográfico regional, diferenciado, e do desempenho econômico pior de vários estados, como mostrei acima. Como a taxa demográfica do NE $(1,3 \%)$ foi ainda menor do que a do país, sua renda média ganhou alguns pontos, atingindo o nível equivalente a $47 \%$ da renda média nacional.

Enfim, os dados mostram que o tema da convergência/divergência em termos regionais, não pode ser analisado apenas pelos dados da renda média, salvo quando a economia cresce vigorosamente por todo o território nacional, e não como tem ocorrido nestas últimas décadas de crise.

Quanto ao movimento migratório inter-regional, analisado entre 1991 e 2000, seus dados são muito preocupantes. O fluxo do período somou 4 milhões de pessoas, média anual $66 \%$ maior do que no período anterior. Por outro lado: 
- para a região NO rumaram apenas 255 mil, o que causou surpresa, contra 832 mil do período anterior, e suas saídas aumentaram $50 \%$, ameaçando converter a região, de receptora em expulsora;

- no CO-DF, entraram 507 mil contra 636 mil no período anterior e suas saídas cresceram 10\%;

- para SP, que se pensava como uma área que não permitiria maiores fluxos entraram 1,7 milhão, cuja média anual é o dobro da verificada no período anterior;

- o NE continuou a ser o maior expulsador, dele emigrando 2,3 milhões, 1,3 milhões para SP, 246 mil para o NO e 232 mil para o CO-DF;

- o PR continuou a "limpeza" de seu campo, expulsando mais 232 mil pessoas e MG 126 mil.

Resultou assim que ao final do período, praticamente apenas SP - com todos os seus graves problemas urbanos e sociais - permanecia como o grande receptor da migração nacional, e as demais regiōes (além do NO e $\mathrm{CO}$ ) ou se tornaram expulsadoras ou reduziram drasticamente suas capacidades de recepção.

Enquanto a população rural diminuía (de 35,8 milhôes para 31,9 milhões), a urbana crescia à media anual de $2,44 \%$ abaixo da taxa da década anterior (2,97\%). Cresceram abaixo da média nacional: SP, RJ, RS, RN, PB e PE; o NO teve a mais alta (4,8\%), seguido pelo CO-DF (3,2\%). Desconcentração produtiva, expansão da fronteira agro-mineral e fluxos migratórios ampliaram e desconcentraram a urbanização. A taxa de urbanização do Brasil passou a $81,2 \%$, sendo as do NO e NE as menores, pouco acima de $69 \%$ e SP, RJ e DF as maiores, acima de $93 \%$. A do CO-DF foi a quarta maior $(84,8 \%)$, resultado da transformação de sua moderna agropecuária e da agroindustrialização.

A PEA total cresceu à média anual de 2,98\% mas a PEA ocupada só de 1,92\%, mostrando cerca de 12 milhōes de pessoas desocupadas. A PEA agrícola diminuiu de 12 milhões para 11,8 milhões e a não agrícola, aumentou de 43,3 milhões para 53,9 milhões.

Dados da PEA mostram a grave situação do emprego. ${ }^{23}$ Os censos de 1991 e 2000 mostram forte redução de 30\% na PEA agrícola ocupada do Brasil; no NO e CO-DF, as reduçôes respectivas foram de $22 \%$ e $20 \%$, em que pese o forte aumento de seus PIBs agrícolas (32\%) e de suas áreas plantadas (53\%). É óbvio que os efeitos mais perversos disso atingem mais os trabalhadores de baixa renda. Trabalho recente, abarcando as PNADs de 1999 a 2003, mostra a continuidade do fenômeno: forte aumento da área plantada e redução do emprego em $5,5 \%{ }^{24}$ É ainda mais grave que a proporção dos trabalhadores rurais sem remuneração (mais de 15 horas semanais trabalhadas) na PEA, só diminuiu um pouco para o agregado Brasil (de 3,2\% para 3,1\%), no Sul e CO-DF, aumentando nas demais regiōes. Em termos absolutos, essa categoria só diminuiu em SP e no Sul.

$\mathrm{Na}$ indústria não foi melhor: a criação de 575 mil empregos na construção civil não pode compensar os 1.109 mil desempregados nos outros setores industriais, restringindose a criação de empregos urbanos praticamente ao setor de serviços. Porém, o que cresceu mais no urbano foi o grupo dos sem remuneração (mais de 15 horas semanais trabalhadas), em todas as regiōes, crescendo 166\% no Brasil; em segundo, o de empregado doméstico remunerado, com $36 \%$ e em terceiro os autônomos (onde predomina o trabalho precarizado e informal) com $19 \%$. Se "tudo ou mais ficasse constante", a situação dos trabalhadores de baixa renda teria piorado, em consequência do forte aumento da informalidade e precarização no trabalho urbano.

Mas os números mascaram um mero efeito estatístico de "melhoria distributiva", uma vez que grande parte desses novos empregos está na verdade substituindo outros
23 Estou usando os dados da chamada PEA restrita, ou seja, estimada pela mesma metodologia do Censo de 1991, dado que a PEA, na metodologia do Censo de 2000 , não é diretamente comparável à de 1991 . Os dados foram gentilmente cedidos por meu colega professor Cláudio Dedecca. Para essa discussão metodológica. ver Dedecca e Rosandiski (2003).

240 texto é o de Balsadi (2005). Ver também Belik e outros (2003). 
25 Cf. Pochmann (2006).

26 Dados contidos em matéria do jornalista Fernando Dantas, publicada no Estado de São Paulo, em 9-4-2007, Caderno Metrópole.

27 Sobre o tema das cidades médias, ver Andrade e Serra (2002). tipos de trabalho (menos precários), anteriormente exercidos por essas pessoas, nos quais seus rendimentos eram maiores. Baltar, em trabalho recente, já havia mostrado isso, analisando as PNADs de 1989 e 1999. Nele se vê que os aumentos mais expressivos no mercado de trabalho urbano foram os mais precarizados e informais, notadamente de emprego domiciliar, limpeza, segurança e serviços auxiliares. O emprego urbano, naquele período, cresceu apenas $16,8 \%$ ao passo que o dos autônomos aumentou $42,3 \%$ e dos domésticos 37,7\%.

O DIEESE confirma esses fatos. Entre 1991 e 2000, para a RMSP, a taxa de desemprego aberto saltou de $7,9 \%$ para $11 \%$ e a do desemprego total de $11,7 \%$ para $17,6 \%$. $\mathrm{O}$ rendimento real médio anual do total dos trabalhadores assalariados do setor privado caiu $26,2 \%$, o dos com carteira assinada caiu $25,3 \%$ mas o dos sem carteira caiu apenas 2,1\%. Esta última cifra esconde o citado "efeito estatístico de melhoria", que pode ser melhor observado na relação entre o rendimento médio dos sem carteira e o dos com carteira assinada: era de 48,4\% em 1991, subindo para 70,7\% em 2000. Em que pese isso, entre 1980 e 2000, o número de famílias ricas no Estado de São Paulo passou de 192 mil para 674 mil, ou 58\% do total nacional. Só na cidade de São Paulo residem 40\% do total estadual. Isso se deve, em grande medida, ao rentismo que crassa nas famílias de alta renda no Brasil. ${ }^{25}$

Como essa dinâmica afetou mais seriamente RJ e SP, e dada a situação prévia em que se encontrava o problema social nessas áreas, não é difícil entender as razões básicas que explicam o extraordinário aumento da violência nesses dois estados, agora já não mais radicada apenas em suas duas maiores cidades, mas já espraiada em quase todas as cidades de médio e grande porte do país. Entre 1985 e 2005, o emprego formal ligado à segurança pessoal e pública na cidade de São Paulo passou de 95,6 mil pessoas para 446 mil, ou seja, 366\% de aumento, enquanto o dos professores aumentou apenas $38 \%$. Na cidade do Rio de Janeiro, os números passaram de 67,8 mil pessoas para 245 mil, ou $270 \%$ de aumento. ${ }^{26}$

Por tamanho de cidade, as maiores de 1 milhão de habitantes incorporam Guarulhos (SP), passando a 13 e as maiores de 500 mil e menores de 1 milhão passam de 13 a 18 , das quais faziam parte 6 do NE, 6 de SP e 3 do RJ. As cidades médias, que já vinham crescendo mais do que as RMs na década anterior, continuaram a fazê-lo, assimilando não só os efeitos positivos da expansão urbana, mas, principalmente, os nocivos: conurbação, periferização, favelização; insuficiência de recursos públicos, insegurança, degradação ambiental e outros males. ${ }^{27}$

\section{O Período 2003-20IO}

Neste tópico, as principais questôes macroeconômicas nacionais serão tratadas mais resumidamente do que nos anteriores. Os temas da questão regional e da urbanização, por terem sido muito menos pesquisados, serão aqui apontados em suas linhas muito gerais, e deverão, portanto, receber atenção mais detalhada nas proposiçōes que faço para a pesquisa.

Nos dois mandatos do governo Lula, as linhas mais gerais da política macroeconômica seguiram praticamente a mesma orientação neoliberal do governo anterior: câmbio valorizado, abertura comercial, maior desregulamentação financeira, juros reais elevados, superávit fiscal primário, investimento público baixo e crédito (menos) contido.

No segundo mandato houve um abrandamento do crédito: seu provimento ao setor privado passou de $25 \%$ para cerca de $45 \%$ do PIB; aumento de prazos de financiamento 
ao consumo e forte expansão dos limites do BNDES. As políticas sociais foram positivas, com o Bolsa Família e recuperação parcial do salário mínimo e das aposentadorias. Isto reativou o crescimento do consumo, mas a taxa de investimento, embora crescesse, oscilou entre os 18\%-19\% do PIB. A partir de 2003-2004 os estímulos internacionais da elevada expansão da China ("efeito China") e os decorrentes da aceleração da especulação financeira internacional elevaram sobremodo os preços de quase todas as commodities, beneficiando extraordinariamente nossas exportaçōes primárias.

O dólar barato constrangeu as exportações de manufaturados e alargou o deficit comercial nesses bens, diminuindo nossa competitividade externa e a participação desses produtos na pauta exportadora. Esse debilitamento e mais a guerra fiscal entre as UFs, tem desestruturado nosso parque industrial, avançando o processo de desindustrialização. A participação da indústria de transformação no PIB caiu ainda mais, atingindo 15,7\% em 2010!

Ao mesmo tempo o forte aumento dos gastos externos pessoais e de remessas de empresas privadas provocaram crescentes deficits em transaçôes correntes. Dada a elevada taxa real de juros e a situação internacional, o buraco de nossas contas externas foi coberto por uma enxurrada de dólares, com grandes sobras, aumentando nossas reservas, diminuindo a dívida externa pública e criando a ilusão de que "nossa vulnerabilidade externa agora é baixa". Os otimistas "esqueceram" de analisar com mais responsabilidade nossos passivos externos, e mais precisamente, os enormes investimentos externos em carteira. Pior ainda, que o dólar barato também estimula a saída de capital nacional, atitude que também tem sido apoiada pelo crédito do BNDES.

A crise internacional também nos pegou em 2008-2009, mas graças às políticas "anticíclicas" implementadas - principalmente as grandes isenções e os largos prazos de financiamento ao setor automobilístico e a expansão do crédito público para o setor habitacional -, nos recuperamos a partir de fins de 2009.

O crescimento médio anual (2003-2010) do PIB foi de 4,4\%, graças às taxas mais altas da mineração $(5,5 \%)$ e dos serviços $(4,5 \%)$, dado que a agropecuária $(2,2 \%)$ e a indústria de transformação $(2,8 \%)$ sentiram mais os efeitos da crise. Ainda assim, a expansão do consumo e das exportações primárias está criando a ilusão do crescimento, e da hipótese de que a situação excepcional do mercado internacional perdure a longo prazo. Chegamos, portanto, a um ponto de saturação desse modelo, mas "ninguém quer pôr o guizo no gato", ou "tirar o bode da sala".

A boa média anual do crescimento do PIB entre 2003 e 2010 (salvo 2009) suscitou no governo, nos economistas conservadores e nas elites, uma euforia, anunciando que a "recuperação dos fundamentos" - o deficit público, o do comércio exterior e o menor nível de inflação -, nos levara ao crescimento "sustentado" (no sentido econômico, não no ambiental). Que não teríamos mais nosso conhecido "voo da galinha”. Recusam-se a ver que os "bons fundamentos" e os "maus e escorchantes juros" não recuperaram a estrutura e o volume dos investimentos - notadamente do industrial -, e que nos mantemos em crescimento, graças à excepcional situação do mercado internacional de commodities e à ameaça de quebra de certos "fundamentos", como o crédito contido e o gasto social e do aumento do salário mínimo, do que às virtudes de nossa política econômica.

Não é preciso repisar os males sociais advindos da dinâmica do modelo neoliberal: aumento do desemprego, queda dos salários reais, corte dos gastos sociais e aumento da violência, hoje presentes em todas as nossas regiôes e cidades. Assim, é inerente a essa dinâmica, a corrosão (e não o equilíbrio) dos chamados fundamentos da economia, que, fatalmente, a conduz a um desastre cambial e financeiro. 
28 Em Cano (2010) apresento as linhas gerais do que seria um Projeto Alternativo para o Brasil, com o vetor principal do crescimento voltado para a distribuição de renda e de ativos e a expansão do mercado interno, não descurando contudo de retomar a atualização tecnológica imprescindível para recuperarmos e ampliarmos nossas exportações de manufaturados.

29 Para uma síntese crítica desses Planos, ver Guimarães (2006).
Existem alternativas a esse modelo. ${ }^{28}$ Mas é preciso que se entenda que é impossível, imediatamente, fazermos a reestruturação produtiva e da infraestrutura, dada a enorme massa de recursos para isso exigidos. Assim, é preciso estabelecer prioridades nacionais; uma nova política de crescimento e um maior controle dos capitais e do comércio exterior, e um radical enfrentamento da questão social do país.

Para tanto, necessitamos de muito tempo para fazê-lo, e de muita negociação política. Acima de tudo, necessitamos reconstruir o estado e dotá-lo de recursos compatíveis, tanto para o saneamento estrutural fiscal quanto para a retomada do investimento público. Somente em uma alternativa como esta é que se pode pensar seriamente no trinômio estabilidade, retomada do crescimento e resgate da dívida social. Somente com ela é que se pode repensar a questão regional e a urbana em termos produtivos e sociais.

\section{A Questão Regional no Período}

Em termos regionais, continuou a ausência de Políticas de Desenvolvimento Regional e os recursos públicos minguados, a despeito de que o principal órgão do desenvolvimento regional - o Ministério da Integração Nacional - tenha se empenhado desde 2004 na formulação de planos regionais de desenvolvimento, os quais, apesar de sua boa qualidade, não têm sustentação do contexto macro nacional, pela ausência de uma política nacional de desenvolvimento. ${ }^{29}$

Contrapondo-se a essa crescente omissão do Estado, aumentou em muito o efetivo poder político e econômico de grandes grupos privados, nacionais ou não, sobre alguns importantes espaços do território nacional, mormente no NO, CO-DF e em algumas partes do NE. Contudo, há que examinar o quanto suas ações se prendem fundamentalmente ao objetivo de lucro e quanto delas resulta em benefícios para o desenvolvimento da região em que atuam. O desmatamento do $\mathrm{NO}$ e do CO-DF, a precariedade do emprego urbano e disseminação de centros urbanos de baixo padrão de qualidade, se não superam os efeitos positivos daquelas ações, é evidente que anulam boa parte deles.

Pelas Contas Regionais (CRs), o PIB do Brasil, entre 2003 e 2008 teria crescido à média anual de $4,5 \%$ e o de SP $5,1 \%$. Contudo, as mesmas CRs mostram que a participação de SP no total nacional cai de 33,8\% para 32,0\%. O mesmo ocorre na indústria de transformação, em que a taxa do país foi de $3,8 \%$ e a de SP 4,7\%, caindo de novo - sem que se saiba a causa - a participação paulista, de $44,1 \%$ para $43,7 \%$. Idêntico fato no setor de serviços, com as respectivas taxas de crescimento de 4,8\% e 5,5\%, mas caindo a participação paulista de $33,8 \%$ para $33,4 \%$.

Um rápido exame das participações de cada região e Unidade da Federação (UF) no total nacional mostra muitas outras contradições ou dados surpreendentes, como por exemplo, o insignificante aumento da participação do CO-DF no PIB total (de 5,4\% para 5,5\%) e no da agropecuária (de 17,4\% para 17,5\%). Evidentemente há que examinar cuidadosamente as CRs, comparar as mudanças entre as metodologias 1985 e 2002 e compará-las com outras informaçôes.

É evidente que a desconcentração produtiva continuou em todos os grandes setores: é a consolidação da fronteira agropecuária do $\mathrm{NO}$ e do CO-DF - e do aumento da ocupação dos cerrados da BA, PI e MA pelas commodities exportáveis, da consolidação da província mineral de Carajás, da grande expansão do petróleo no RJ, ES e RN. Mesmo porque a guerra fiscal continuou a funcionar a todo vapor. É preciso advertir que essa "nova economia" tem sido equivocadamente chamada de especializaçôes regionais, quando 
na verdade se trata das conhecidas bases produtivas de recursos naturais. $\mathrm{O}$ termo especialização em economia tem um sentido claro como algo que decorre de um aprofundamento da divisão social do trabalho, de algo não comum, como é uma commodity.

Por outro lado, precisamos entender que mesmo que venhamos a ter no futuro longos períodos de firme crescimento, a expansão da periferia estará atrelada, em grande medida, à região de São Paulo. Tanto porque não há sentido teórico nem prático em se pensar em uma "industrialização autônoma" para o resto do Brasil. A exceção a esse processo reside na "autonomia" regional ganha por algumas áreas do país, com a expansão de produção destinada a exportações (notadamente de commodities) e à produção energética, como o álcool de cana, o petróleo e a hidroeletricidade.

Contudo, à medida que o mercado interno cresça espacialmente e possa ser amparado por uma infraestrutura adequada e dissemine economias de escala e externas - ambas no sentido produtivo e tecnológico - para a industrialização, esta seguirá se desconcentrando. Pistas para essas possibilidades podem e devem ser buscadas por meio da análise dos dados do comércio inter-regional e das estruturas produtivas regionais. Os últimos dados que pude acessar sobre esse comércio são para 1999 e eles mostram que suas exportações para o restante do país equivaliam a 45\% do PIB paulista e as importaçóes a 34\%, afluxos que representavam o dobro de seus fluxos de comércio exterior.

Isto não elimina a necessidade de se discutir e implantar medidas específicas de crescimento ou que possam atenuar ou corrigir os desequilíbrios regionais e sociais mais gritantes existentes no país. É óbvio que esforços no sentido de alocação de projetos em outras áreas do país devem e podem ser feitos por meio de programas e projetos de impacto detalhados de forma "mais fina". Os de recursos privados, contudo, em sua busca por maiores "vantagens locacionais", ajudaram a aumentar a suicida "guerra fiscal" entre estados brasileiros, promovendo verdadeiros leilóes de localização.

A desconcentração no sentido São Paulo para o restante do país, se mantida a política neoliberal, continuará tendo um alto componente espúrio, e padecerá, crescentemente, dos efeitos perversos que a desestruturação industrial está causando. Tais efeitos não só têm prejudicado ainda mais a economia paulista, como também afetam o parque industrial nacional, destruindo cadeias produtivas e inibindo economias de escala e externas.

\section{A Questão Urbana no Período}

A taxa de crescimento da população total caiu fortemente entre os períodos 19912000, quando foi $1,61 \%$ e o de 2000 e 2010 , quando atingiu 1,18\%. Redução ainda mais drástica deu-se na taxa de crescimento da população urbana, caiu de $2,44 \%$ para $1,57 \%$. Enquanto nossa população rural diminuía em 2 milhões, a urbana crescia mais 23 milhōes. A redução daquelas taxas se deu em todas as regiōes e UFs, sendo as taxas mais altas, respectivamente a total e a urbana, as do NO (2\% e 2,6\%) e CO-DF (1,8\% e 2,1\%).

Por corte de tamanhos de cidades, Campinas-SP e São Luis-MA aumentam para 15 o número de cidades milionárias e o de cidades entre 500 mil e 1 milhão passa de 18 para 23, das quais estão 7 no NE e 6 em SP. Contudo, a expansão foi maior no número de cidades médias e pequenas, pelo fato de seu crescimento demográfico continuar a ser maior do que nas grandes, e ainda devido à criação de 58 municípios na década.

Cabe aqui repisar uma questão importante, mas que tem sido menos considerada nos estudos propositivos para as cidades médias e pequenas, em termos de políticas sociais. Não se pode esquecer que suas dinâmicas de crescimento e a forma que ele assume 
decorrem de suas inserções nas redes urbanas principais ou mais relevantes de que fazem parte. O que se pode ver nos dados existentes, é que as cidades de porte médio e grande têm assimilado os efeitos perversos das maiores e das RMs, muitas vezes sem assimilar seus principais efeitos positivos. Assim, o sentido dessas propostas de políticas públicas é parcial, aparentemente esquecendo que a massa maior daqueles problemas se encontra nas maiores.

A taxa de urbanização atingiu $84,4 \%$ para o Brasil, próxima à do Sul (84,9\%). As do NO e NE subiram, de cerca de $69 \%$ para $73 \%$ tornando territorialmente menos concentrado o processo de urbanização.

Até agora (junho de 2011) foram poucos os dados divulgados do Censo de 2011, razão pela qual o tema urbano, neste tópico, será bem menos tratado. Para as migrações, usei provisoriamente os dados de várias PNADs (de 1999 a 2009) apenas para ter algumas informações que me possibilitassem conhecer pelo menos a "tendência" ao longo do período. Com esses dados, pude fazer o seguinte resumo, que deverá ser confrontado pelos dados do Censo:

- as entradas no NO e no CO-DF devem ter se mantido em torno de, respectivamente, 300 mil e 500 mil pessoas, com pequena diminuição no NO. As saídas do CO-DF tiveram pequeno aumento, mas as do NO aumentaram em 100 mil, diminuindo sua capacidade receptora;

- as entradas em SP teriam sido fortemente reduzidas, de 1,7 milhões na década anterior, para cerca de 650 mil nesta, também diminuindo a capacidade receptora. Os imigrantes do NE teriam somado 330 mil e os de MG, 200 mil;

- as saídas do NE tiveram forte redução, caindo de 2,3 milhões para 1,1 milhão nos mesmos períodos. Esse fluxo teria um destino majoritário para o NO, CO-DF e SP, distribuído em proporções semelhantes pelas três regiões;

- de MG, as saídas aumentaram muito, passando de 127 mil para 350 mil;

- as do PR caem, de 366 mil para 150 mil, dando a entender que sua reestruturação agrícola e agrária tenha sido concluída.

Aparentemente, os fluxos neste período, teriam tido um destino muito mais urbano do que rural, mas isto requer o exame aprofundado dos dados censitários de 2010, tanto os migratórios quanto os de emprego. Vejamos dois fatos. O maior fluxo de emigrantes nordestinos se dirigiu a SP, onde a população rural diminuiu em 760 mil pessoas, número maior do que o total de imigrantes do estado e o dobro do de nordestinos. Em GO também diminuiu a população rural (menos 23 mil pessoas), mas o fluxo de nordestinos teria sido em torno de 180 mil. Em MS e MT a população rural aumentou pouco mais de 6\% com números absolutos bem próximos aos dos imigrantes.

Já na região NO, em que a população rural aumentou 8\% (309 mil pessoas) o fluxo nordestino (cerca de 300 mil pessoas) distribuiu-se entre todos os estados que também ampliaram a população rural, e se concentraram no PA (cerca de 180 mil). Neste estado, fiz um teste sobre a região Sudeste, que foi a que mais cresceu - em termos econômicos e demográficos - mas que se caracterizou pela forte presença da mineração em Carajás, da pecuária latifundiária e da subsistência rural. Dado o pouco emprego gerado pela mineração e pela pecuária, é surpreendente que $90 \%$ do crescimento da população total foi urbano.

Estes fatos apontam para a grande diversidade das determinaçôes regional e urbana que ocorreu nos últimos períodos, tanto em termos econômicos, quanto ocupacionais e demográficos, o que está exigindo uma série de pesquisas específicas para tentar explicar 
esses fatos e, quiçá, poder estimular a elaboração e posta em prática de políticas públicas para enfrentar os graves problemas regionais e urbanos do país.

É sabido que vários indicadores sociais no Brasil têm melhorado, mas não se sabe o quanto dessa melhora se deve à efetividade de políticas públicas e quanto ao fato de que nossa estrutura etária mudou muito, diminuindo fortemente certas demandas sociais. Por exemplo, quanto da "melhoria" do grau de atendimento educacional nos últimos 20 anos se deve à política educacional e quanto se deve ao simples fato de que entre 1991 e 2010 o número de crianças com menos de 10 anos de idade se reduziu em 15\%, ou seja, porque temos hoje 5,2 milhões delas a menos.

Contudo, e pensando no futuro, já ingressamos, há vários anos, em um processo que nos está conduzindo a um expressivo amadurecimento e envelhecimento da população brasileira, e isto nos traz a certeza de que no futuro teremos duas questóes muito importantes que deveriam, desde já, ser analisadas:

- as demandas sociais estão crescendo e vão crescer ainda mais, pois o grupo etário maior de 60 anos dobrou, aumentando em 10 milhôes de pessoas, e isto pressiona fortemente os gastos com saúde, assistência social e previdência, muito mais do que se fossem 10 milhões de crianças;

- o grupo entre 14 e 65 anos cresceu $46 \%$ ou 39 milhóes de pessoas em idade de trabalhar, e também crescerá ainda mais nos próximos anos, pressionando energicamente o mercado de trabalho.

\section{PROPOSTAS DE INVESTIGAÇÃO}

As propostas de pesquisa que seguem terão a periodização aqui anunciada, ou, quando for o caso, terão uma periodização específica.

\section{As Questốes de Ordem Geral}

Em termos macroeconômicos, há uma questão central que decorre da sustentabilidade econômica do atual modelo, à qual já me referi. Ou seja, é preciso fazer uma reflexão crítica sobre as circunstâncias atuais da economia internacional e sobre as condições internas. A médio prazo, que desfecho ou que rumos poderão ter a crise financeira internacional? Qual a duração provável do extraordinário boom dos preços das commodities? Idem, quanto ao chamado "efeito China"? Creio que enquanto essas questôes não sofrerem alterações profundas, tampouco será possível repensar sobre a integração sul-americana.

Não se trata aqui de fazer pesquisa propriamente dita, mas sim de refletir sobre os caminhos e cenários mais prováveis e, daí, pesquisar os efeitos que deles emanariam sobre as dinâmicas de crescimento nacional e regional e do processo de urbanização.

Arrisco um exercício de simulação: que diferenças substanciais teríamos naquelas dinâmicas, se fizéssemos uma radical mudança em direção mais ao mercado interno e à redistribuição de renda, e menos à manutenção da abertura comercial e financeira?

Mas há ainda pesquisas que tanto cabem em termos nacionais quanto regionais, por exemplo, a da desindustrialização e a guerra fiscal, às quais voltarei no item seguinte. Será útil um mapeamento das principais políticas públicas criadas ao longo dos períodos de análise, em especial as de infraestrutura geral e urbana, as principais políticas sociais e as poucas medidas de caráter regional ou urbano. 


\section{Sobre a Questão Regional}

30 Cano (2008).

31 A pesquisa referida é a da Tese de Livre Docência de Fernando M. Mota (2010) que mostra forte elevação dos coeficientes de exportação e de importação. Contudo, as mudanças metodológicas das CRs, alterando valores e estruturas dos PIBs regionais e a valorização cambial podem distorcer muito os valores desses coeficientes. Os dados anteriores a 1989 estão contidos em antigas publicações do IBGE ou do Banco Central, mas envolvem problemas metodológicos sobre a origem estadual de várias dessas exportações. ções para sua reversão? todas as UFs. crescimento regional:
A pesquisa a que me referi ${ }^{30}$ e que estou usando largamente neste texto, informa várias questôes sobre as novas determinaçôes, particularmente as emanadas do aparelho produtivo, que vem sofrendo alterações estruturais ao longo do período 1970-2003. Contudo, é preciso examinar outras, que não foram objeto daquela pesquisa ou que, por suas especificidades, foram tratadas de modo parcial ou pouco detalhado.

A guerra fiscal e a desindustrialização, embora já tenham sido objeto de vários estudos e pesquisas, se ressentem ainda da falta de dados concretos sobre seus efeitos. São exemplos: que fins esses processos têm sobre os custos de inversão e de produção e da rentabilidade privada? Eles seriam rentáveis e competitivos sem os incentivos recebidos? Em que medida estes investimentos incentivados pela guerra fiscal são do tipo footloose, e, portanto podem ter uma temporalidade mais curta? As destruiçóes causadas por esse processo e pela desindustrialização são reversíveis? Sob que condições? Lideranças empresariais desaparecidas, empresas falidas ou alienadas, elos eliminados de cadeias produtivas, mercados externos perdidos, podem ser facilmente recriados?

Ainda, pode-se especular sobre a Zona Franca de Manaus, instituição peculiar, pois que, como Zona Franca, deveria ser exportadora líquida para o exterior, mas que na realidade é deficitária, desde sua origem. Se o modelo macroeconômico nacional fosse alterado, diminuindo drasticamente a abertura e desvalorizando o câmbio, haveria condi-

Os dados do comércio interestadual depois de 1985 ficaram ainda mais precários propositadamente ocultos ou de pobre informação, face aos problemas políticos gerados por sua divulgação, frente à guerra fiscal. Os do comércio exterior de cada UF são fornecidos pelo Ministério do Desenvolvimento, para o período posterior a 1989 e foram objeto de recente pesquisa que analisou seus impactos estruturais sobre a economia e a urbanização das várias UFs, mas requerem ainda um aprofundamento analítico sobre o emprego e a renda, e, no período posterior a 2003, sobre o efeito negativo do crescimento desproporcional das importações. ${ }^{31}$

Essa pesquisa mostra, por exemplo, que as exportações do PA representam 90\% das do NO, mas as importações do Amazonas (ZFM) totalizam cerca de $90 \%$ da região, mostrando impactos distintos nesses dois estados. Indica ainda que as exportações de produtos básicos em recursos naturais têm elevado peso no total exportado pelo NO (80\%), NE (60\%) e CO-DF (905\%). Já os produtos industriais predominam nas exportações do Sul e SP, e as importações de manufaturados estão fortemente presentes em praticamente

Essas e as questões abaixo devem constituir uma pesquisa sobre as determinações do

- principalmente para o período mais recente, analisar as mudanças nas estruturas produtivas e de emprego das regiōes;

- a expansão da produção nas áreas de fronteira agropecuária e mineral: regiôes NO, CO-DF e os cerrados da BA, PI e MA;

- a forma e os resultados da profunda reestruturação agrária e agrícola que se verificou nos estados do PR e RS, com a implantação e expansão do complexo soja-trigo;

- surgimento ou expansão de novos pontos de concentração de atividades que não existiam em seus respectivos novos espaços. São exemplos: a forte expansão da atividade petrolífera nas regiōes norte fluminense, sul do ES, e litoral de SE e do RN; a 
maturação da fábrica da Fiat em MG, os novos polos automobilísticos do RS, PR, BA e GO; a fruticultura de Petrolina-Juazeiro; o polo calçadista do CE; perspectivas para o polo de Suape (PE). Examinar ainda os investimentos no RN, CE e PE da ordem de 25 bilhōes para energia eólica, aumentando a participação dela na matriz energética de $1,3 \%$ para $5,3 \%$ até $2014 ;^{32}$

- pesquisar a articulação de novos investimentos em minérios e para além dos minérios pela Vale na região Norte, provocando efeitos espacialmente diferenciados; retomada dos grandes projetos hidrelétricos; expansão das usinas de biocombustíveis (etanol);

- estudo especial deve ser feito sobre e Zona Franca de Manaus, implantada em 1967 e que vai amadurecendo a partir da década de 1980;

- aprofundar estudo dos principais impactos espaciais da expansão do comércio exterior na década, notadamente de commodities (soja, carnes e minérios);

- idem quanto ao comércio inter-regional, cujos dados são muito precários para esse período;

- principais efeitos da guerra fiscal sobre as estruturas de custos de produção e competitividade com empresas que não foram incentivadas. Sua continuidade será capaz de confirmar as teses sobre fragmentação da economia nacional?;

- idem quanto à desindustrialização e principais efeitos destrutivos de cadeias produtivas, mormente nos setores automobilísticos e de eletrônica.

\section{Sobre a Questão Urbana}

Existem muitos trabalhos publicados sobre essas questōes, mas é indispensável a realização (ou aprofundamento) de análises de vários problemas que ocorreram no período. ${ }^{33}$ As dificuldades com o necessário processamento dos Censos Demográficos de 1980 e de 1991 constituem sérios obstáculos, alguns dos quais talvez possam ser solucionados com o uso de fontes alternativas, usadas com muita cautela. Como principais fatos a pesquisar:

- a expansão, extensão e o aumento da densidade da urbanização foram espacialmente diferenciados, e, portanto é preciso fazer um mapeamento dos principais focos de expansão e tentar, com o auxílio das pesquisas aqui apontadas, esclarecer suas determinações. Como exemplos disto: a forte expansão e concentração urbana em Manaus; a elevada expulsão de trabalhadores e pequenos proprietários rurais do PR; o início da ocupação rural e mineral no Sudeste do PA, e outros;

- as principais mudanças na estrutura do emprego regional (se necessário, com recortes sub-regionais) emanadas das transformações produtivas tratadas neste tópico;

- examinar as mudanças da estrutura espacial da distribuição de renda;

- aprofundar a análise do setor de serviços (via Censo Demográfico), e a interdependência direta e indireta deste fato com as mudanças produtivas. Em outras palavras: indagar que mudanças no emprego - especialmente do urbano - e na oferta/demanda de serviços, que foram geradas pela expansão da fronteira agropecuária ou pelos fatos especiais ocorridos na década (Zona Franca de Manaus, petróleo no RJ, ES, SE e RN; principais polos automobilísticos etc.);

- aprofundar os estudos das migrações inter-regionais para poder relacioná-las com as grandes mudanças produtivas acima referidas. Em alguns estados - como no PA, examinar as migrações intrarregionais recentes;
32 Valor Econômico, 28/04/2011.

33 Dos trabalhos mais gerais cabe citar: IPEA-NESUR (2001), IBGE (2008) e IPEA (2011). 
- fazer um mapeamento dos assentamentos de reforma agrária para entendê-los como novos componentes desses movimentos demográficos regionais;

- utilizar as pesquisas disponíveis sobre rede urbana, para localizar e separar, nas UFs, os efeitos decorrentes de metropolização, aglomeração, conurbação e periferização;

- confrontar via Censos e outras fontes, indicadores sociais urbanos nos espaços das UFs e em seus respectivos espaços realçados nestas pesquisas, em especial os indicadores vinculados ao tema do saneamento básico (água, esgoto, lixo e meio ambiente);

- exame sumário da situação das finanças públicas municipais: capitais, RMs e cidades de maior relevância para a urbanização do período;

- exame circunstanciado da expansão do setor imobiliário e estudos sobre a questão habitacional (questão fundiária: produção e uso de solo urbano).

\section{ALGUNS PROBLEMAS METODOLÓGICOS}

Por último, cabe advertir que existem vários problemas de ordem metodológica e de informação, para os quais devemos estar alertas e tentar, na medida do possível, contornálos. Entre os principais, cabe destacar os seguintes:

- a difícil e, em alguns casos impossível compatibilização (não só de caráter espacial) entre as PNADs e os Censos Demográficos;

- idem, quanto às Contas Regionais e os Censos Agrícolas, as PIAs e as PINPFs no período pós 1985, que comumente apresentam dados controvertidos entre essas fontes, especialmente com relação à desconcentração produtiva regional;

- o fato de que as PNADs só a partir de 2004 apresentam dados sobre a zona rural da região Norte;

- o fato de que os dados do comércio inter-regional têm divulgação precária e muito interrupta, embora os dados primários estejam centralizados no Confaz;

- para o movimento e estrutura do emprego, embora a RAIS seja anual, só abarca o emprego formal; para o emprego total praticamente só contamos com os Censos Demográficos (decenais), dados os problemas de compatibilidade já apontados para com as PNADs;

- as Contas Nacionais e as Regionais têm sofrido recentemente várias mudanças metodológicas que muitas vezes alteram fortemente dados passados já divulgados e analisados. Por outro lado, a forte valorização cambial que padecemos desde 1994 certamente alterou muitos preços relativos e os próprios coeficientes de comércio exterior;

34 Sempre que não existam, naquele recorte espacial, pelo menos três estabelecimentos do mesmo segmento produtivo.
Wilson Cano é professor titular do Centro de Estudos de Desenvolvimento Econômico do Instituto de Economia/Unicamp.Email: wcano@eco. unicamp.br

Artigo recebido em agosto de 2011 e aprovado para publicação em outubro de 2011.
- com relação às PIAs, embora o IBGE proporcione tabulações especiais (nacionais ou regionais) detalhando os dados a 3 ou mais dígitos, ele não evita o problema do sigilo estatístico, ${ }^{34}$ tornando, em muitos casos, inviável o uso daqueles dados.

\section{REFERÊNCIAS BIBLIOGRÁFICAS}

ANDRADE, T.; SERRA, R. "Notas sobre a experiência de crescimento recente das Cidades Médias Brasileiras”. In: KON, A. Unidade e Fragmentação: a questão regional no Brasil. São Paulo: Perspectiva, 2002.

AFFONSO, R.B.A.; SILVA, P.B. (Orgs.) Federalismo no Brasil-desigualdades regionais e desenvolvimento. São Paulo: FUNDAP-UNESP, 1995, 2v. 
AFONSO, J. R.; VARSANO, R. (2004). "Reforma Tributária: sonhos e frustraçōes". In: GIAMBIAGI, F. e outros (Orgs.) Reformas no Brasil: balanço e agenda. Rio de Janeiro: Nova Fronteira, 2004.

ARAUjO, T. B. "Por uma Política Nacional de Desenvolvimento Regional". Revista Econ. Do Nordeste, BNB, Fortaleza, 4-6/1999. . Ensaios sobre o desenvolvimento brasileiro: heranças e urgências. Rio de Janeiro, Revan, 2000.

BALSADI, O. V. "Comportamento das Ocupações na Agropecuária Brasileira no período 1999-2003”. Informação Econômica, São Paulo, v. 35, n. 9, set. 2005.

BALTAR, P.E.A. "Estrutura econômica e emprego urbano na década de 1990". In: PRONI, M.W.; HENRIQUE, W. (Orgs.). Trabalho, Mercado e Sociedade. Campinas: Unesp/ Unicamp, 2003.

BELIK, W. e outros. "O emprego rural nos anos 90”. In: PRONI, M. W.; HENRIQUE, W. (Org.). Trabalho, Mercado e Sociedade. Campinas Unesp/Unicamp, 2003.

BRANDÃO, C. A. A Dimensão Espacial do Subdesenvolvimento: uma agenda para os estudos urbanos e regionais. Unicamp, Instituto de Economia, Tese de Livre Docência, Campinas, 9/2003.

BERCOVICI, G. Desigualdades Regionais, Estado e Constituição. São Paulo: Ed. MaxLimonad, 2003.

CANO, W. Soberania e Politica Econômica na América Latina. São Paulo: Editora Unesp/ Unicamp-IE, 2000.

2007 (A), 5a. ed.

Raizes da Concentração Industrial em São Paulo. Campinas: IE/Unicamp,

. Desequilibrios Regionais e Concentração Industrial no Brasil (1930-1970).

São Paulo: Unesp, 2007 (B), 3․ ed.(revista e modificada).

. Desconcentração Produtiva Regional do Brasil: 1970-2005. São Paulo:

Unesp, 2008.

. "Uma Agenda Nacional para o Desenvolvimento". Revista Tempo no Mundo, IPEA, Brasília, v.2, n.2, 12/2010.

. Ensaios sobre a Economia Urbana do Brasil. Campinas: Ed. Unicamp (no prelo), 2012.

. e outros (Coords.). Economia Paulista: dinâmica socioeconômica entre 1980 e 2005. Campinas: Alínea, 2007.

CARDOSO, S. A Guerra Fiscal no Brasil. Tese de Doutoramento, Instituto de Economia, Unicamp, 2010.

CAVALCANTI, C. E. G.; NOVAIS, L. F.; BONINI, M. R. "Análise das Finanças Públicas do Estado de São Paulo: 1980 a 2004”. In: CANO, W. e outros (2007) (Coords.). Economia Paulista: dinâmica socioeconômica entre 1980 e 2005. Campinas: Alínea, 2007.

CAVALCANTI, C. E. G.; PRADO, S. Aspectos da guerra fiscal no Brasil. Rio de Janeiro/ São Paulo: IPEA/FUNDAP, 1998.

CARVAlHO, F. F. Da Esperança à Crise - A Experiência das Políticas Regionais no Nordeste. Dissertação de Mestrado. Instituto de Economia, Unicamp, Campinas, 2001.

DEDECCA, C. S.; ROSANDISKI, E. Sensos e Dissensos: as inovaçôes metodológicas do Censo Demográfico 2000. Campinas: Unicamp/Instituto de Economia/CESIT, 2003 (mimeo.). 
DINIZ, C. C. "Território e Nação". In: REZENDE, F.; TAFNER, P. O estado de uma nação. Brasília: IPEA, 2005.

FURTADO, C. Análise do Modelo Brasileiro. Rio de Janeiro: Civilização Brasileira, 1972, $3^{\mathrm{a}}$ ed.

GALVÃO, A.C.F. Politica de Desenvolvimento Regional e Inovação: lições da experiência européia. Rio de Janeiro: Garamond, 2004.

GALVÃO, A. C. F.; BRANDÃO, C. A. "Fundamentos, motivações e limitações da proposta dos 'Eixos Nacionais de Integração e Desenvolvimento'”. In: GONÇALVES, M. F., BRANDÃO, C. A.; GALVÃO, A. C. F. Regiōes e cidades, cidades nas regiōes. O desafio urbano-regional. São Paulo: Ed. Unesp, 2003.

GEIGER, P. P. Evolução da rede urbana brasileira. Rio de Janeiro: Inst. Nacional de Estudos Pedagógicos, Ministério da Educação e Cultura, 1963.

GUIMARÃES N. "Desigualdades e Políticas Regionais no Brasil: Caminhos e Descaminhos". Revista Planejamento e Politicas Públicas. Brasília: IPEA, junho de 1997, n. 15.

. "Formação de uma Agenda para o Desenvolvimento Regional". Ministério

da Integração Nacional, Boletim Regional n. 3, Brasília, set-dez/2006. (IBGE - REGIC (2007) Região de Influência da cidade.) IBGE, Brasília, 2008.

IPEA - Dinâmica Urbano-Regional-Rede Urbana e suas Interfaces. Ipea, Brasília, 2011.

IPEA-NESUR - Configuração Atuale Tendência da Rede Urbana Brasileira. IPEA-NESUR/ Unicamp/Inst. de Economia. Brasilia, 2001.

LOPREATO, F. L. C. O colapso das finanças estaduais e a crise da federação. São Paulo/ Campinas: Ed. Unesp/Unicamp, 2002.

MAHAR, D. J. Desenvolvimento Econômico da Amazônia, Rio de Janeiro: IPEA, 1978.

MONTEIRO NETO, A. Desenvolvimento Regional em Crise: Politicas Econômicas. Liberais e Restrições à Intervenção Estatal no Brasil dos Anos 90. Tese de Doutoramento. Unicamp/Instituto de Economia, Campinas, 2005.

MOTA, F. C. M. Inserção Externa e Território: impactos do comércio exterior na dinâmica regional e urbana no Brasil (1989-2008). Tese de Livre Docência, Unicamp, Instituto de Economia, Campinas, 2010.

PACHECO, C. A. Fragmentação da Nação. Campinas: IE/Unicamp, 1998.

PIMES - Desigualdades Regionais no Desenvolvimento Brasileiras. Recife, Sudene, 4 v., 1984.

PINTO, M. P. A.; CINTRA, M. A. M.; CAVALCANTI, C. E. G. Crise e "ajuste” das finanças do estado de São Paulo (1980-2005). In: PINTO, M. P. A.; BIASOTO, G. B. Politica Fiscal e Desenvolvimento no Brasil. Campinas: Ed. Unicamp, 2006.

POCHMANN, M. "São Paulo, décadence avec élégance”. Valor, p. A13, São Paulo, 2812-2006.

PRADO, S. "Distribuição Intergovernamental de Recursos na Federação Brasileira”. In: Descentralização e Federalismo Fiscal no Brasil. REZENDE, F.; OLIVEIRA, F. A. (Orgs.) FGV-F. K. Adenauer, Rio de Janeiro, 2003.

SILVA, M. A. Guerra Fiscal e Finanças Federativas no Brasil. Unicamp/IE, Dissertação de Mestrado, Campinas, 2001.

A B S T R A C T Between 1930 and 1980, urbanization process, domestic market integration and regional development in Brazil were basically determined by the combination of industrialization process, macroeconomic and regional development policies. After 1980, 
as a result of the so called "Lost decade" and the implementation of neoliberal policies, those determinants were significantly modified by the new paths of external insertion, overvalued exchange rate, high interest rates, and "fiscal war" between regions. Beyond those weakened previous determinants, new ones have aroused; some are national and others specific to each region. Despite the changes in the determinants mentioned above, the harmful side-effects of the economic growth and urbanization processes have affected the whole national territory. As a conclusion, the article proposes a Research Agenda focused on regional and urban subjects for the period 1980-2010 in order to better understand how those determinants have affected these processes.

K E Y W O R D S Regional development; urbanization; new determinants; fiscal war; Brazil's international position. 